Karadağ, Ö. (2019). Türkçe ders kitaplarında yer alan özetleme etkinlikleri üzerine bir değerlendirme. Ana Dili Eğitimi Dergisi, 7(2), 469-485.

$\begin{gathered}\text { Ana Dili Eğitimi Dergisi } \\ \text { Journal of Mother Tongue Education } \\ \text { www.anadiliegitimi.com }\end{gathered}$
Geliş/Received: 30.07 .2018 Kabul/Accepted:29.04.2019
Araştırma Makalesi / Research Paper

\title{
Türkçe Ders Kitaplarında Yer Alan Özetleme Etkinlikleri Üzerine Bir Değerlendirme
}

\author{
Özay KARADAĞ*
}

\section{Öz}

Özetlemek, var olan bir düşünceyi, izlenen bir içeriği, dinlenen veya okunan bir metni olduğundan daha kısa ve özünü yansıtacak biçimde yazılı veya sözlü olarak anlatmaktır. Özetleme becerisi karmaşık bilişsel süreçler içermektedir. Özetleme yapabilmek için bir öğrencinin metinde önemli noktaların vurgulanış biçimlerini kavraması, önemli bilgiyi önemsiz bilgiden ayırt edebilmesi, not alabilmesi, metnin konusunu belirleyebilmesi, ana fikri ve yardımcı fikirleri bulabilmesi, metin türünü ve yapısını çözümleyebilmesi gerekmektedir. Bir anlatı metni veya bilgilendirici metni özetleme sürecinde öğrencilerden sınıflama, sıralama, değerlendirme, karar verme becerilerini kullanmaları beklenir. Silme, genelleme ve yeniden kurma olarak üç aşamalı modellenen özetlemenin öğrenciler tarafından kavranması ve uygulanması, uzun süreli ve tekrarlı bir eğitim süreci gerektirir. Türkçe Dersi Öğretim Programı'nda (2018) özetleme kazanımları 5.-8. sınıf düzeylerinde, dinleme ve okuma becerileri altında yer almaktadır. Öğrenciler, öğrenme sürecinde, özetleme görevleriyle Türkçe ders kitaplarında yer alan etkinliklerde karşılaşmaktadır. Türkçe ders kitaplarındaki etkinliklerin, özetlemenin bilişsel yükleri dikkate alınarak oluşturulması gerekmektedir. Bu çalışmada, 2018-2019 eğitim-öğretim yılında yürürlükte olan ortaokul Türkçe ders kitaplarında yer alan özetleme etkinlikleri incelenmiştir. Araştırmada ortaya çıkan en temel sonuç, Türkçe ders kitaplarının tamamında özetleme etkinliklerinin büyük çoğunluğunun, özetlemenin bilişsel süreçlerine uygun olarak oluşturulmaması ve öğrencilerden doğrudan bir metnin özetinin istenmesidir. Ayrıca, özet görevlerinin büyük bir çoğunlukla yazılı olduğu ve özet metinlerinin değerlendirilmesine yönelik uygulamalara sadece bir kez yer verildiği araştırmanın diğer bulgularıdır.

Anahtar Kelimeler: özet, özetleme, Türkçe ders kitapları, özet etkinlikleri

\section{An Evaluation of the Summarizing Activities in Turkish Textbooks}

\begin{abstract}
Summarizing means presenting a written thought, a monitored content, a text that is heard or read, in written or oral form, which is shorter and reflect its main idea. The ability to summarize involves complex cognitive processes. To summarize, a student should be able to comprehend the ways of emphasizing important points, distinguish significant information from insignificant one, take notes, determine the subject of the text, find the main idea and supporting ideas, and analyze the text type and structure. In the process of summarizing a narrative text or an informative text, students are expected to use classification, sorting, evaluation and decision-making skills. Elimination, generalization and reconstruction of the three-stage model requires a long-term and repeated training process for students to understand and implement. Summarizing acquisitions take place in the Turkish Language Teaching Program (2018) in the $5^{\text {th }}$ and the $8^{\text {th }}$ grades listening and reading skills. Students encounter summarizing tasks and activities in Turkish textbooks in their learning processes. The activities in Turkish textbooks should be formed by considering the cognitive complexity of summarizing. In this study, summarizing activities in secondary school
\end{abstract}

\footnotetext{
* Doç. Dr, Hacettepe Üniversitesi Eğitim Fakültesi Türkçe ve Sosyal Bilimler Eğitimi Bölümü, Ankara,
} ozaykaradag@hacettepe.edu.tr, ORCID: 0000-0003-4596-1203 
Turkish textbooks in 2018-2019 academic year were examined. Findings of the study suggest that most summarizing activities in Turkish textbooks are not formed in accordance with the cognitive processes of summarizing and a direct summary of the text is requested from the students. In addition, findings of the study show that summarizing tasks are mostly in a written form, and activities for the evaluation of the summary texts are presented only once.

Keywords: summary, summarizing, Turkish textbooks, summarizing activities

\section{Giriş}

Türkçe Sözlük (2011: 1868) özetlemek eylemini “bir yazı, konu, söz veya filmin içeriğini daha az sözle anlatmak, özünü vermek, kısaltmak, hülasa etmek" şeklinde tanımlamaktadır. Özetlemek, var olan bir düşünceyi, izlenen bir içeriği, dinlenen veya okunan bir metni, olduğundan daha kısa ve özünü yansıtacak biçimde yazılı veya sözlü olarak anlatmaktır. Özetleme, çoğunlukla okunan/dinlenen metinler için gerçekleştirilen bir eylem olarak algılansa da aslında, sadece metne bağlı olmayıp, günlük hayatın bir anlatma pratiği olarak sıkça başvurulan bir dil işlevidir. Bu işlev, zaman kısıtlaması olan durumlarda, anlam aktarımının daha kısa, ancak genel anlamı ortaya koyacak biçimde, yapılarak iletişim ihtiyacının giderilmesini sağlamaktadır.

Eğitim açısından bakıldığında, özetleme becerisinin daha çok metin temelli ele alındığı görülmektedir. Ülper ve Karagül (2011:145) özetlemeyi bir edim olarak niteleyerek, bir kaynak metnin bilişsel işlemler sonucunda daha kısa bir metne dönüştürülme işlemi şeklinde tanımlamakta ve bu işlemlerin ardından üretilen yeni metne özet adını vermektedir. Dilidüzgün (2008:104) metnin ayrıntılarının atılıp önemli noktaları korunarak yazılı veya sözlü, daha kısa olarak yapılan anlatıma özet demektedir. Çıkrıkçı (2008) özetlemeyi, önemli bilgiyi daha az önemli bilgiden ayırma yoluyla, kaynak metin üzerinde gerçekleştirilen işlevsel bir kısaltma eylemi olarak tanımlamaktadır.

Dil eğitimi açısından özetleme, anlama becerileri olan dinleme ve okumayla anlatma becerileri olan konuşma ve yazma arasında kesişim noktası oluşturmaktadır. Özetleme, bilişsel bir ürün olarak kavrama basamağı altında sınıflanmakla birlikte (Senemoğlu, 2018) aynı zamanda bir anlatma eylemidir. Bir yönü mutlak biçimde anlama olan özetleme, kaynak metnin sınırları içinde kalarak daha özlü ve kısa biçiminin ortaya konması sebebiyle özgün olmayan bir anlatımdır. Öyle ki, özetleme sürecinde okurun veya dinleyicinin kaynak metne yapacağı ilaveler özetin niteliğini düşürür. Bu yönüyle özetleme, özetleyenin ne kadar anladığını ortaya koyar. "Okuyucunun veya dinleyicinin bir metni ana noktalarına indirgeme yeteneği, içeriği iyi kavradığı anlamına gelirken metni düzgün olarak özetleyememesi metni yanlış bir biçimde kavradığı anlamına gelir" (Kim, 2001; Cho, 2012).

Özetleme karmaşık bilişsel süreçler içermektedir. Bu bakımdan kavrama düzeyinin en üst ürünü olarak değerlendirilebilir ve bu basamak içinde hiyerarşik olarak birçok bilişsel işlemin ön koşul olarak gerçekleşmesi gerekir. Özetleme yapabilmek için bir öğrencinin metinde önemli noktaların vurgulanış biçimlerini kavraması, önemli bilgiyi önemsiz bilgiden ayırt edebilmesi, not alabilmesi, 
metnin konusunu belirleyebilmesi, ana fikri ve yardımcı fikirleri bulabilmesi, metin türünü ve yapısını çözümleyebilmesi gerekmektedir. Bir anlatı veya bilgilendirici metni özetleme sürecinde sınıflama, sıralama, değerlendirme, karar verme becerilerinin kullanılması beklenir.

Karmaşık bilişsel işlemleri dolayısıyla, özetleme işlemi birden çok aşamadan oluşmaktadır. Kintsch ve van Dijk (1978) metin anlama modeli olarak küçük ölçekli ve büyük ölçekli metin yapısı içinde önermelerin seçici olarak işlenmesi gerektiğini vurgulayarak silme, genelleme ve yeniden kurma aşamalarını tanımlamaktadır. Buna göre kavranan metinler zihinde yaklaşık özetleriyle temsil edilir (Kim, 2001). Zikredilen anlamlandırma aşamaları, metin özetlemenin de aşamaları olarak birçok çalışmada model olarak kabul edilmektedir (Kim, 2001; Cho, 2012; Deneme ve Demirel 2012; Karatay, 2014; Dilidüzgün, 2013; Marzec-Stawiarska, 2016).

Silme, genelleme ve yeniden kurma aşamalarının her birinin altında birden çok bilişsel işlem gerçekleşir ve bu işlemler için temel beceriler kullanılır. Silme işlemi için öncelikle metindeki bilgilerin belirlenmesi, bu bilgilerin sınıflanması, karşılaştırılması ve hangilerinin önemli hangilerinin önemsiz olduğuna karar verilmesi gerekir. Genellemede, metindeki kavramlar sınıflanarak üst kategorilere, bir başka deyişle anlamı koruyacak genel kavrama ulaşılır. Bunun yanı sıra eylemler arasındaki alt eylemlilik özelliği dikkate alınarak, önermelerin genellenmesi gerekir. Yeniden kurma aşamasında, yapılan genellemeler değerlendirilir ve yazarın oluşturduğu anlam sınırları içinde özet metni inşa edilir.

Öğrenciler eğitim sürecinde sık sık özetleme göreviyle karşılaşır. Özetleme, öğrenciler için metni anlama düzeyiyle birlikte genel anlatma düzeyinin de bir göstergesidir. Özetleme yapamayan bir öğrenci metindeki fikirlerin gelişimini takip edemez. "Metnin ana fikrini, bu ana fikrin hangi yardımcı fikirlerle ve örneklerle desteklendiğini belirleyemeyen öğrencilerin metinden hatırladıkları çoğu zaman birbiriyle bağlantılı olmayan bilgilerdir" (Kim, 2001). Bu sebeple eğitim sürecinde öğrencilerin etkili bir özetleme becerisi kazanması hedeflenmelidir.

Türkçe Dersi Öğretim Programı (2018) özetlemeye, 5, 6, 7. ve 8. sınıflarda, dinleme ve okuma öğrenme alanlarında, "Dinlediklerini/izlediklerini özetler." ve "Okuduklarını özetler." kazanımlarıyla yer vermektedir. Bunun yanı sıra 7. ve 8. sınıflar okuma öğrenme alanında "Okuma stratejilerini kullanır." kazanımı altında "Göz atarak, özetleyerek, not alarak, işaretleyerek ve tartışarak okuma gibi yöntem ve teknikleri kullanmaları sağlanır." açıklaması içinde özetleyerek okuma bir teknik olarak tanımlamaktadır. Program, 7. ve 8. sınıflar yazma öğrenme alanında "Yazma stratejilerini uygular." kazanımı altında "Not alma, özet çıkarma, serbest, kontrollü, kelime ve kavram havuzundan seçerek yazma, bir metinden hareketle yazma ve duyulardan hareketle yazma gibi yöntem ve tekniklerin kullanılması sağlanır." açıklaması içinde, özet çıkarmayı kullanılması istenen bir teknik olarak tanımlamaktadır. 
Bu çalışmada Türkçe Dersi Öğretim Programı́nın (2018) ortaokul düzeyinde, dinleme, okuma ve yazma öğrenme alanlarında öğrencilere kazandırmayı hedeflediği özetleme becerisinin Türkçe ders kitaplarında nasıl ele alındığı araştırılmıştır. Bu amaçla 2018-2019 eğitim-öğretim yılında Millî Eğitim Bakanlığı (MEB) tarafından kabul edilen ve yürürlükte olan 5. sınıflar için bir, 6. sınıflar için iki, 7. sınıflar için üç, 8. sınıflar için bir olmak üzere toplam 7 adet Türkçe ders kitabındaki özetleme etkinlikleri incelenmiştir.

\section{Yöntem}

Araştırma bir durum çalışmasıdır. Araştırma bilgi içeren dokümanlar aracılığıyla bir durum hakkında derinlemesine bilgi toplama, betimleme ve tematik olarak ortaya koyma (Creswell, 2016) imkânı veren bütüncül tek durum çalışmasıdır. Araştırmanın inceleme nesneleri 2018 yılında yürürlüğe giren Türkçe Dersi Öğretim Programı ve 2018-2019 eğitim-öğretim yılında yürürlükte olan ortaokul ve imam hatip ortaokulları Türkçe ders kitaplarıdır. İnceleme nesnesi olan Türkçe ders kitapları şunlardır:

Tablo 1. Inceleme Nesnesi Olarak Belirlenen Ortaokul Türkçe Ders Kitapları

\begin{tabular}{lll}
\hline Sınıf Seviyesi & Kitabın Adı & Yayınevi \\
\hline 5. Sınıf & $\begin{array}{l}\text { Ortaokul ve Imam Hatip Ortaokulu Türkçe Ders } \\
\text { Kitabı 5 }\end{array}$ & MEB Yayınları \\
\hline 6. Sınıf & $\begin{array}{l}\text { Ortaokul ve Imam Hatip Ortaokulu Türkçe 6 Ders } \\
\text { Kitabı }\end{array}$ & MEB Yayınları \\
\cline { 2 - 3 } & 6. Sınıf Ortaokul Türkçe Ders Kitabı & Eksen Yayıncılık \\
\hline 7. Sınıf & $\begin{array}{l}\text { Ortaokul ve Imam Hatip Ortaokulu Türkçe 7. sınıf } \\
\text { Ders Kitabı }\end{array}$ & MEB Yayınları \\
& $\begin{array}{l}\text { Ortaokul ve Imam Hatip Ortaokulu Türkçe Ders } \\
\text { Kitabı 7 }\end{array}$ & MEB Yayınları \\
& $\begin{array}{l}\text { Ortaokul ve Imam Hatip Ortaokulu Türkçe 7 Ders } \\
\text { Kitabı }\end{array}$ & Dersdestek Yayıncılık \\
& $\begin{array}{l}\text { Ortaokul ve Imam Hatip Ortaokulu Türkçe 8 Ders } \\
\text { Kitabı }\end{array}$ & MEB Yayınları \\
\hline 8. Sınıf & & \\
&
\end{tabular}

Araştırmanın verileri yazııı ve görsel malzemelerin toplanıp incelenmesi (Sönmez ve Alacapınar, 2014) esasına dayanan doküman incelemesi tekniği elde edilmiştir. Doküman analizinde, özetleme temel kategori olarak belirlenmiş ve öncelikle Türkçe Dersi Öğretim Programı (2018) kazanımlarda özetlemeye yer vermesi bakımından incelenmiştir. íkinci olarak ortaokullar için hazırlanan yürürlükteki Türkçe ders kitaplarının tamamında yer alan özetleme etkinlikleri incelenmiştir. Verilerin çözümlenmesinde şu aşamalar takip edilmiştir:

-Sınıf içinde öğrenme yaşantısı oluşturacak şekilde hazırlanması gereken özetleme etkinliklerinin öğrenciler açısından nasıl bir öğrenme süreci oluşturduğu,

-Birden çok bilişsel süreç içeren özetleme işleminin nasıl yapılandırıldığı,

-Etkinliklerde özetlemenin basamaklarına yer verilip verilmediği, verilmişse nasıl yer verildiği. 
Türkçe Ders Kitaplarında Yer Alan Özetleme Etkinlikleri Üzerine Bir Değerlendirme

\section{Bulgular}

Türkçe Dersi Öğretim Programına ilişskin Bulgular

Türkçe Dersi Öğretim Programı'nda (2018) özetlemeyle ilgili kazanımlar ortaokul 5. sınıf düzeyinden itibaren başlamakta ve her sınıf düzeyinde de yer almaktadır. Doğrudan özetlemeyle ilgili kazanımlar öğrenme alanlarına göre şunlardır:

Dinleme

T.5.1.5. Dinlediklerini/izlediklerini özetler.

T.6.1.3. Dinlediklerini/izlediklerini özetler.

T.7.1.3. Dinlediklerini/izlediklerini özetler.

T.8.1.3. Dinlediklerini/izlediklerini özetler.

Okuma

T.5.3.13. Okuduklarını özetler.

T.6.3.16. Okuduklarını özetler.

T.7.3.15. Okuduklarını özetler.

T.8.3.13. Okuduklarını özetler.

Kazanım Altı Açıklamalarda Özetlemeye İlişkin Bulgular

Özetlemenin 7. Sınıf düzeyinden itibaren kazanımların altında yapılan açıklamalarda bir teknik olarak belirtildiği görülmekte, bu tekniklerin kullanılması istenmektedir. Özetlemenin bir teknik olarak önerildiği kazanımlar ve alt açıklamaları öğrenme alanlarına göre şunlardır:

Okuma

T.7.3.4. Okuma stratejilerini kullanır.

Göz atarak, özetleyerek, not alarak, işaretleyerek ve tartışarak okuma gibi yöntem ve teknikleri kullanmaları sağlanır.

T.8.3.4. Okuma stratejilerini kullanır.

Göz atarak, özetleyerek, not alarak, tartışarak ve eleştirerek okuma gibi yöntem ve teknikleri kullanmaları sağlanır.

Yazma

T.7.4.4. Yazma stratejilerini uygular. 
Not alma, özet çıkarma, serbest, kontrollü, kelime ve kavram havuzundan seçerek yazma, bir metinden hareketle yazma ve duyulardan hareketle yazma gibi yöntem ve tekniklerin kullanılması sağlanır.

T.8.4.4. Yazma stratejilerini uygular.

Not alma, özet çıkarma, eleştirel, yaratıcl, serbest, kelime ve kavram havuzundan seçerek yazma, bir metinden ve duyulardan hareketle yazma gibi yöntem ve tekniklerin kullanılması sağlanır.

\section{Türkçe Ders Kitaplarına iliş̧kin Bulgular}

Tablo 2. Ortaokul Türkçe Ders Kitaplarında Özetleme Etkinliklerinin Genel Dağılımı

\begin{tabular}{|c|c|c|c|}
\hline $\begin{array}{c}\text { Sinıf } \\
\text { Seviyesi }\end{array}$ & Kitabın Adı & Yayınevi & $\begin{array}{l}\text { Özetleme Etkinliği } \\
\text { Sayısı }\end{array}$ \\
\hline 5. Sinıf & $\begin{array}{l}\text { Ortaokul ve İmam Hatip Ortaokulu } \\
\text { Türkçe Ders Kitabı } 5\end{array}$ & MEB Yayınları & 6 \\
\hline \multirow[t]{2}{*}{ 6. Sinıf } & $\begin{array}{l}\text { Ortaokul ve İmam Hatip Ortaokulu } \\
\text { Türkçe Ders Kitabı } 6\end{array}$ & MEB Yayınları & 5 \\
\hline & 6. Sınıf Ortaokul Türkçe Ders Kitabı & Eksen Yayıncılık & 5 \\
\hline \multirow[t]{3}{*}{ 7. Sinıf } & $\begin{array}{l}\text { MEB Ortaokul ve İmam Hatip } \\
\text { Ortaokulu Türkçe } 7 \text { Ders Kitabı }\end{array}$ & MEB Yayınları & 8 \\
\hline & $\begin{array}{l}\text { Ortaokul ve İmam Hatip Ortaokulu } \\
\text { Türkçe Ders Kitabı } 7\end{array}$ & MEB Yayınları & 11 \\
\hline & $\begin{array}{l}\text { Ortaokul ve İmam Hatip Ortaokulu } \\
\text { Türkçe Ders Kitabı } 7\end{array}$ & $\begin{array}{l}\text { Dersdestek } \\
\text { Yayıncılık }\end{array}$ & 6 \\
\hline 8. Sinıf & $\begin{array}{l}\text { Ortaokul ve İmam Hatip Ortaokulu } \\
\text { Türkçe Ders Kitabı } 8\end{array}$ & MEB Yayınları & 7 \\
\hline
\end{tabular}

MEB Ortaokul ve Imam Hatip Ortaokulu Türkçe Ders Kitabı 5

Bu ders kitabında 5 özetleme etkinliği yer almaktadır. Etkinlik yönergeleri temalara, metinlere ve sayfa sırasına göre şunlardır:

Tablo 3. MEB Ortaokul ve Imam Hatip Ortaokulu Türkçe Ders Kitabı 5'e Illişkin Bulgular

\begin{tabular}{|c|c|c|c|c|c|}
\hline Sira & $\begin{array}{l}\text { Beceri } \\
\text { Alanı }\end{array}$ & Tema & Metin & Etkinlik Yönergesi & Sayfa \\
\hline 1 & Okuma & $\begin{array}{l}\text { Çocuk } \\
\text { Dünyası }\end{array}$ & $\begin{array}{l}\text { Ben Bir Çınar } \\
\text { Ağacıydım }\end{array}$ & $\begin{array}{l}\text { a) Aşağıda daha önce okuduğunuz } \\
\text { “Oyuncak" adlı metnin örnek bir özeti } \\
\text { verilmiştir. Özeti okuyunuz. } \\
\text { b) Aşağıdaki alana “Ben Bir Çınar } \\
\text { Ağacıydım” metninin özetini yazınız. } \\
\text { Özetinizi yazarken öğretmeninizin } \\
\text { verdiği ipuçlarından yararlanınız. }\end{array}$ & 28 \\
\hline 2 & Okuma & $\begin{array}{l}\text { Çocuk } \\
\text { Dünyası }\end{array}$ & $\begin{array}{l}\text { Hayalden Gerçeğe } \\
\text { (Tema } \\
\text { Değerlendirme } \\
\text { Sorusu) }\end{array}$ & $\begin{array}{l}\text { Yukarıdaki metni kendi cümlelerinizle } \\
\text { özetleyiniz. }\end{array}$ & 36 \\
\hline 3 & Okuma & Erdemler & Püf Noktası & “Püf Noktası” metninin özetini yazınız. & 90 \\
\hline 4 & Okuma & $\begin{array}{l}\text { Millî } \\
\text { Kültürümüz }\end{array}$ & Forsa & $\begin{array}{l}\text { Aşağıdaki bölüme metnin özetini } \\
\text { yazınız. }\end{array}$ & 142 \\
\hline
\end{tabular}


Türkçe Ders Kitaplarında Yer Alan Özetleme Etkinlikleri Üzerine Bir Değerlendirme

\begin{tabular}{clllll}
\hline 5 & Okuma & $\begin{array}{l}\text { Doğa ve } \\
\text { Evren }\end{array}$ & $\begin{array}{l}\text { Kar Tanesinin } \\
\text { Serüveni }\end{array}$ & $\begin{array}{l}\text { Aşağıda verilen bölüme metnin özetini } \\
\text { yazınız. }\end{array}$ & 239 \\
\hline 6 & $\begin{array}{l}\text { Dinlem } \\
\text { e }\end{array}$ & $\begin{array}{l}\text { Doğa ve } \\
\text { Evren }\end{array}$ & Kuş ağacı & Dinlediğiniz metni özetleyiniz. & 243 \\
\hline
\end{tabular}

Bu kitapta altı özetleme etkinliği bulunmaktadır. Etkinliklerden beşi okuma, biri dinleme becerisine yöneliktir. Okuma becerisine yönelik etkinliklerden biri Tema Değerlendirme Soruları içinde yer almaktadır. Burada, verilen bir metnin özetlenmesi istenmiştir.

Kitapta ilk sırada yer alan etkinlik diğerlerinden farklı olarak iki aşamalı oluşturulmuştur. Aynı tema içinde daha önce işlenmiş bir metnin özeti örnek olarak verilmiş ve öğrencilerden okumaları istenmiştir. i̇kinci aşamada öğrencilerden, bu örneği ve öğretmenin vereceği ipuçlarını kullanarak hedef metni özetlemeleri istenmiştir. Aynı metin için hazırlanan hikâye haritası etkinliği (s.23'te) özet çalışmasıyla ilişkilendirilebileceği hâlde böyle bir yola gidilmemiştir. Öğrenciler için model oluşturması beklenen örnek özetin de hangi açılardan ele alınıp inceleneceğine ilişkin bir ölçüt belirtilmemiştir. Öğrencinin, örnek özeti kendi başına çözümlemesi ve özet yazmanın ilkelerini belirlemesi gerekmektedir ki bu da 5. sınıf öğrencisi açısından baş edilemez bilişsel karmaşa yaratabilir. Etkinlikte öğretmenin vereceği ipuçları hem örnek özetin çözümlenmesi hem de özetlemenin ilkelerinin fark edilmesi ve yeni duruma uygulanması bakımından kritik hâle gelmektedir.

Kitapta yer alan diğer etkinliklerde öğrencilerin özetleme yapabildiği kabul edilmekte ve öğrencilerden doğrudan hedef metinleri özetlemeleri istenmektedir. Etkinliklerde not alma, ana fikir bulma, silme, genelleme vb. gibi özetlemenin alt bilişsel işlemlerinin herhangi biriyle ilişkilendirme yapılmamıştır. Dört etkinlik yönergesi “...metnin özetini yazınız." veya “...metni özetleyiniz." ifadeleriyle bitmektedir. Bunun yanı sıra, yönergelere göre öğrencilerden sözlü özet istenmemektedir. Ayrıca özet metinlerinin değerlendirilmesine yönelik herhangi bir uygulamaya yer verilmemiştir.

MEB Ortaokul ve Imam Hatip Ortaokulu Türkçe 6 Ders Kitabı

Tablo 4. MEB Ortaokul ve Imam Hatip Ortaokulu Türkçe 6 Ders Kitabı'na ilişkin Bulgular

\begin{tabular}{|c|c|c|c|c|c|}
\hline Sira & $\begin{array}{l}\text { Beceri } \\
\text { Alanı }\end{array}$ & Tema & Metin & Etkinlik Yönergesi & Sayfa \\
\hline 1 & Okuma & $\begin{array}{l}\text { Okuma } \\
\text { Kültürü }\end{array}$ & Canım Kitaplığım & $\begin{array}{l}\text { Öğretmeniniz metni okurken } \\
\text { metni özetlemek amacıyla not } \\
\text { alınız. Ardından siz de metni } \\
\text { sesli okuyunuz. Metni } \\
\text { okuduktan sonra aldığınız } \\
\text { notlardan hareketle metni } \\
\text { özetleyiniz. }\end{array}$ & 26 \\
\hline 2 & Okuma & Erdemler & Vermek Çoğalmaktır & $\begin{array}{l}\text { Okuduğunuz metnin özetini } \\
\text { aşağıya yazınız. }\end{array}$ & 110 \\
\hline 3 & Dinleme & Erdemler & Balıkçıl & Dinlediğiniz metni özetleyiniz. & 126 \\
\hline 4 & Okuma & $\begin{array}{l}\text { Birey ve } \\
\text { Toplum }\end{array}$ & Sen de Bir İyilik Yap & Okuduğunuz metni özetleyiniz. & 254 \\
\hline
\end{tabular}




\begin{tabular}{|c|c|c|c|c|c|}
\hline 5 & Okuma & $\begin{array}{l}\text { Birey ve } \\
\text { Toplum }\end{array}$ & $\begin{array}{l}\text { Hacettepe } \\
\text { (Ana metin Dinleme } \\
\text { becerisi için } \\
\text { kullanılmıştır. } \\
\text { Özetleme, ders } \\
\text { işlemede kullanılan } \\
\text { "Rize'nin Adı } \\
\text { Üzerine" metni için } \\
\text { istenmektedir.) }\end{array}$ & $\begin{array}{l}\text { Okuduğunuz metni, metnin } \\
\text { kahramanlarından biri olan } \\
\text { Roza'nın ağzından özetleyiniz. }\end{array}$ & 269 \\
\hline
\end{tabular}

Kitapta beş özetleme etkinliği bulunmaktadır. Etkinliklerden dördü okuma, biri dinleme becerisine yöneliktir. Okuma becerisine yönelik etkinliklerden biri ders işlemede kullanılan yardımcı bir metnin özetlenmesi etkinliğidir. Kitapta yer alan ilk özetleme etkinliği "Hazırlık Çalışması" başlığı altında verilmekte olup öğrencilerden metnin öğretmen tarafından okunması sırasında not almaları, ardından metni sesli okumaları istenmiştir. Alınan notlardan hareketle de metnin özetlenmesi istenmiştir. Not almayla özetlemenin ilişkilendirilmesi doğru olmakla beraber özetlemenin diğer alt bilişsel işlemleriyle ilişkilendirme yoktur. Kitapta yer alan üç etkinlikte metnin doğrudan özetlenmesi istenmektedir. Ders işlemede kullanılan yardımcı metnin özetlenmesinin istendiği son etkinlikte ise diğerlerinden farklı olarak metindeki kahramanların birinin ağzından özet yazılması istenmektedir. "Sen de Bir lyilik Yap" metninde özetleme öncesi yapılması beklenen ana fikir etkinliğinin özet etkinliğinden sonra yer aldığı tespit edilmiştir.

Genel olarak bakıldı̆̆ında kitabın öğrencilerin özetlemeyi yapabildiği varsayımı üzerine kurulduğu söylenebilir. Ayrıca özet metinlerin değerlendirilmesine yönelik herhangi bir uygulama bulunmamaktadır.

Eksen Yayıncılık 6. Sınıf Ortaokul Türkçe Ders Kitabı

Tablo 5. Eksen Yayıncılık 6. Sınıf Ortaokul Türkçe Ders Kitabı'na Ilișkin Bulgular

\begin{tabular}{|c|c|c|c|c|c|}
\hline Sira & $\begin{array}{l}\text { Beceri } \\
\text { Alanı }\end{array}$ & Tema & Metin & Etkinlik Yönergesi & Sayfa \\
\hline 1 & Okuma & Erdemler & Kaynatılmış Tohum & \multirow{3}{*}{$\begin{array}{l}\text { Metni bir kez daha sessiz okuma } \\
\text { yöntemiyle okuyunuz. } \\
\text { Okumanız tamamlanınca } \\
\text { yukarıdaki sorulara verdiğiniz } \\
\text { cevaplardan da yararlanarak } \\
\text { metnin özetini defterlerinize } \\
\text { yazınız. Ardından özetlerinizi } \\
\text { sınıfta arkadaşlarınıza } \\
\text { okuyunuz. }\end{array}$} & 21 \\
\hline 2 & Okuma & $\begin{array}{l}\text { Millî } \\
\text { Kültürümüz }\end{array}$ & $\begin{array}{l}\text { Boş Bir Kümes, } \\
\text { Birkaç Dolu Kalp }\end{array}$ & & 59 \\
\hline 3 & Okuma & $\begin{array}{l}\text { Birey ve } \\
\text { Toplum }\end{array}$ & Ömür Törpüsü & & 149 \\
\hline 4 & Dinleme & $\begin{array}{l}\text { Birey ve } \\
\text { Toplum }\end{array}$ & Sihirli Pasta & $\begin{array}{l}\text { "Sihirli Pasta" adlı metni sınıfta } \\
\text { arkadaşlarınıza özetleyiniz. }\end{array}$ & 158 \\
\hline 5 & Dinleme & Doğa ve Evren & Beyaz Diş & $\begin{array}{l}\text { "Beyaz Diş" adlı metni sınıfta } \\
\text { arkadaşlarınıza özetleyiniz. }\end{array}$ & 231 \\
\hline
\end{tabular}


Türkçe Ders Kitaplarında Yer Alan Özetleme Etkinlikleri Üzerine Bir Değerlendirme

Kitapta beş özetleme etkinliği bulunmaktadır. Etkinliklerden üçü okuma, ikisi dinleme becerisine yöneliktir. Okuma becerisine yönelik etkinlikler "Akııı Okuma" başlığı altında yer almaktadır.

Okuma becerisine yönelik etkinlikler şu şablonla gerçekleştirilmektedir:

\section{A. Akıcı Okuma}

"..." adlı metni, özetleyerek okuma yöntemiyle okuyunuz. Bunun için metni sessiz okuyunuz ve okuma sırasında aşağıda yer alan soruların cevaplarını defterinize yazınız.

- Metinde anlatılan olay nedir?

- Metinde hangi şahıslara yer verilmiştir?

- Metinde "zaman" kavramıyla ilgili hangi bilgilere yer verilmiştir?

- Metinde "yer" kavramıyla ilgili hangi bilgilere yer verilmiştir?

- Metnin serim bölümünde ne anlatılmaktadır?

- Metnin düğüm bölümünde ne anlatılmaktadır?

- Metnin çözüm bölümünde ne anlatılmaktadır?

- Metnin serim bölümüyle çözüm bölümü arasında hangi değişiklikler meydana gelmektedir?

Metni bir kez daha sessiz okuma yöntemiyle okuyunuz. Okumanız tamamlanınca yukarıdaki sorulara verdiğiniz cevaplardan da yararlanarak metnin özetini defterlerinize yazınız. Ardından özetlerinizi sınıfta arkadaşlarınıza okuyunuz.

Şablon, öyküleyici metinlerin özelliklerine göre oluşturulmuştur. Öyküleyici metinlerin kurucu ögeleriyle metin yapısına yönelik oluşturulan sorular okuma öncesinde öğrencilere verilmektedir. Okumanın ardından bu sorulara verilen cevaplardan hareketle özetlemenin oluşturulması istenmektedir. Bu şablon, özetlemede metin türünün yarattığı farklılıkları belirlemek açısından uygun olmakla birlikte silme, genelleme ve yeniden kurma aşamalarını içermektedir.

Kitapta dinleme becerisine yönelik iki özetleme etkinliğinde yazma alanı bırakılmamıştır. Bundan özetlemenin sözlü olarak gerçekleştirileceği anlaşılmaktadır. Öğrencilere, özetin sözlü olarak da yapılması gereken bir anlama etkinliği olduğunu göstermesi bakımından uygulama olumludur. Ancak bu etkinliklerde de özetlemenin alt bilişsel işlemlerine yönelik ilişkilendirme ve özet metinlerin değerlendirilmesine yönelik bir uygulama bulunmamaktadır. 
MEB Ortaokul ve Imam Hatip Ortaokulu Türkçe 7 Ders Kitabı

Tablo 6. MEB Ortaokul ve Imam Hatip Ortaokulu Türkçe 7 Ders Kitabı'na ilişkin Bulgular

\begin{tabular}{|c|c|c|c|c|c|}
\hline Sira & $\begin{array}{l}\text { Beceri } \\
\text { Alanı }\end{array}$ & Tema & Metin & Etkinlik Yönergesi & Sayfa \\
\hline 1 & $\begin{array}{l}\text { Dinleme/ } \\
\text { İzleme }\end{array}$ & Kişisel Gelişim & Naim Süleymanoğlu & $\begin{array}{l}\text { Naim Süleymanoğlu’nun } \\
\text { hayatını maddeler hâlinde } \\
\text { özetleyiniz. }\end{array}$ & 85 \\
\hline 2 & Okuma & $\begin{array}{l}\text { Millî } \\
\text { Kültürümüz }\end{array}$ & $\begin{array}{l}\text { Türkiyem, } \\
\text { Anayurdum, } \\
\text { Sebebim, Çarem }\end{array}$ & $\begin{array}{l}\text { Beğendiğiniz bir “Dede Korkut” } \\
\text { hikâyesini özetleyiniz. } \\
\text { (gelecek derse hazırlık) }\end{array}$ & 114 \\
\hline 3 & Okuma & $\begin{array}{l}\text { Millî } \\
\text { Kültürümüz }\end{array}$ & Deli Dumrul & $\begin{array}{l}\text { "Dede Korkut" hikâyelerinden } \\
\text { bildiğiniz bir hikâyeyi } \\
\text { özetleyerek arkadaşlarınıza } \\
\text { anlatınız. }\end{array}$ & 115 \\
\hline 4 & Dinleme & $\begin{array}{l}\text { Millî } \\
\text { Kültürümüz }\end{array}$ & Deli Dumrul & $\begin{array}{l}\text { Dinlediğiniz “Deli Dumrul” } \\
\text { metnini özetleyiniz. }\end{array}$ & 118 \\
\hline 5 & Okuma & $\begin{array}{l}\text { Bilim ve } \\
\text { Teknoloji }\end{array}$ & $\begin{array}{l}\text { 20100'deki } \\
\text { Yaşamdan Bir Gün }\end{array}$ & $\begin{array}{l}\text { Metnin özetini verilen bölüme } \\
\text { yazınız. }\end{array}$ & 138 \\
\hline 6 & Okuma & $\begin{array}{l}\text { Okuma } \\
\text { Kültürü }\end{array}$ & Okumak Deyince & $\begin{array}{l}\text { Olayın Özeti } \\
\text { (Kitap Okuma Formu'nda yer } \\
\text { alıyor. En son okunan kitap için } \\
\text { doldurulması isteniyor.) }\end{array}$ & 171 \\
\hline 7 & Okuma & Doğa ve Evren & İlk Kar & $\begin{array}{l}\text { Okuduğunuz metnin özetini } \\
\text { aşağıdaki boşluğa yazınız }\end{array}$ & 199 \\
\hline 8 & Dinleme & $\begin{array}{l}\text { Zaman ve } \\
\text { Mekân }\end{array}$ & $\begin{array}{l}\text { Kırkpınar'a Adını } \\
\text { Veren Kırk Yiğit }\end{array}$ & Dinlediğiniz metni özetleyiniz. & 247 \\
\hline
\end{tabular}

Kitapta sekiz özetleme etkinliği bulunmaktadır. İkinci sırada yer alan etkinlik "Gelecek Derse Hazırlı" bölümünde yer aldığından öğrencilerden üçüncü sırada istenen özet etkinliğiyle örtüşsmektedir. Böyle değerlendirildiğinde kitaptaki özetleme etkinliklerinin sayısı yediye düşmektedir.

Illk sırada yer alan etkinlikte özetin maddeler hâlinde yapılması istenmektedir. Üçüncü sırada yer alan etkinlik sözlü özetleme, diğer etkinliklerin tamamı yazılı özetlemedir.

Kitapta yer alan etkinliklerin tamamında özetlemenin aşamalandırılması veya alt bilişsel işlemlerle ilişkilendirilmesi söz konusu değildir. Genel olarak bakıldığında kitabın öğrencilerin özetlemeyi yapabildiği varsayımı üzerine kurulduğu söylenebilir. Ayrıca, özet metinlerin değerlendirilmesine yönelik herhangi bir uygulama bulunmamaktadır.

MEB Ortaokul ve Imam Hatip Ortaokulu Türkçe Ders Kitabı 7

Tablo 7. MEB Ortaokul ve Imam Hatip Ortaokulu Türkçe Ders Kitabı 7’ye Ilişsin Bulgular

\begin{tabular}{|c|c|c|c|c|c|}
\hline Sira & $\begin{array}{l}\text { Beceri } \\
\text { Alanı }\end{array}$ & Tema & Metin & Etkinlik Yönergesi & Sayfa \\
\hline 1 & Okuma & Duygular & Ana İşsiz Kalınca & $\begin{array}{l}\text { "Ana İşsiz Kalınca” metnini kronolojik } \\
\text { sıra ve mantık akışı içinde özetleyiniz. }\end{array}$ & 26 \\
\hline 2 & Okuma & $\begin{array}{l}\text { Millî } \\
\text { Mücadele ve } \\
\text { Atatürk }\end{array}$ & $\begin{array}{l}\text { Mürefteli Kadınlar ve } \\
\text { Emin Astsubay }\end{array}$ & $\begin{array}{l}\text { Metni, okurken altını çizdiğiniz } \\
\text { bölümlerden hareketle özetleyiniz. }\end{array}$ & 50 \\
\hline
\end{tabular}


Türkçe Ders Kitaplarında Yer Alan Özetleme Etkinlikleri Üzerine Bir Değerlendirme

\begin{tabular}{|c|c|c|c|c|c|}
\hline 3 & Okuma & $\begin{array}{l}\text { Millî } \\
\text { Mücadele ve } \\
\text { Atatürk }\end{array}$ & $\begin{array}{l}\text { Sığırtmaç } \\
\text { Mustafa'nın Öyküsü }\end{array}$ & $\begin{array}{l}\text { Aşağıda verilen görsellerden } \\
\text { yararlanarak okuduğunuz metni } \\
\text { özetleyiniz. }\end{array}$ & 57 \\
\hline 4 & Okuma & $\begin{array}{l}\text { Okuma } \\
\text { Kültürü }\end{array}$ & $\begin{array}{l}\text { Kitaplarla Kurulan } \\
\text { Dostluk }\end{array}$ & $\begin{array}{l}\text { Kütüphaneden alarak okuduğunuz } \\
\text { kitaba ait bilgilerden hareketle } \\
\text { aşağıda verilen "Kitap Özet } \\
\text { Formu"nu doldurunuz. } \\
\text { (Form içinde "Özet:...") }\end{array}$ & 84 \\
\hline 5 & Okuma & $\begin{array}{l}\text { Okuma } \\
\text { Kültürü }\end{array}$ & $\begin{array}{l}\text { Okumak Düşünmek } \\
\text { İçindir }\end{array}$ & $\begin{array}{l}\text { Defterinize aldığınız notlardan } \\
\text { hareketle metni özetleyiniz. }\end{array}$ & 88 \\
\hline 6 & Okuma & Erdemler & Kızgın Bir Lira & $\begin{array}{l}\text { "Kızgın Bir Lira” metnini kronolojik } \\
\text { sıra ve mantık akışı içinde özetleyiniz. }\end{array}$ & 123 \\
\hline 7 & Dinleme & $\begin{array}{l}\text { Kişisel } \\
\text { Gelişim }\end{array}$ & $\begin{array}{l}\text { Küçük Şeyler Üzerine } \\
\text { Öykü: İki Dost, Bir } \\
\text { Kuş }\end{array}$ & $\begin{array}{l}\text { Dinlediğiniz metni kronolojik sıra ve } \\
\text { mantık akışı içinde özetleyiniz. }\end{array}$ & 163 \\
\hline 8 & Okuma & $\begin{array}{l}\text { Millî } \\
\text { Kültürümüz }\end{array}$ & Yusufçuk & $\begin{array}{l}\text { Not aldığınız anahtar kelimelerden } \\
\text { hareketle okuduğunuz metni } \\
\text { kronolojik sıra ve mantık akışı içinde } \\
\text { özetleyiniz. }\end{array}$ & 176 \\
\hline 9 & Okuma & $\begin{array}{l}\text { Millî } \\
\text { Kültürümüz }\end{array}$ & $\begin{array}{l}\text { Anadolu'da Kilim } \\
\text { Demek }\end{array}$ & $\begin{array}{l}\text { "Anadolu'da Kilim Demek" metnini } \\
\text { sözlü olarak özetleyiniz. }\end{array}$ & 190 \\
\hline 10 & Dinleme & $\begin{array}{l}\text { Sağlık ve } \\
\text { Spor }\end{array}$ & Broşür & $\begin{array}{l}\text { Dinlediğiniz metni kronolojik sıra ve } \\
\text { mantık akışı içinde özetleyiniz. }\end{array}$ & 222 \\
\hline 11 & Okuma & Sanat & $\begin{array}{l}\text { Geleneksel Türk } \\
\text { Sanatlarından Ebru }\end{array}$ & $\begin{array}{l}\text { Metni okurken defterinize aldığınız } \\
\text { notlardan hareketle okuduğunuz } \\
\text { metni kronolojik sıra ve mantık akışı } \\
\text { içinde özetleyiniz. }\end{array}$ & 243 \\
\hline
\end{tabular}

Ders kitabında 11 özetleme etkinliğine yer verilmiştir. Bu yönüyle ortaokul düzeyinde özetlemeye en çok yer veren ders kitabıdır. Etkinliklerden birinde özetin sözlü yapılması istenmekte, "Kitap Özet Formu" içinde yer alan özetleme yönergesinde de en son okunan kitabın özetinin yazılması istenmektedir.

Dokuz etkinlikte, her birinde farklı olarak kullanılmakla birlikte, kronolojik sıra, altı çizilen bölüm, görseller, not alma, anahtar kelimeleri not alma gibi özetlemenin altında yer alabilecek bilişsel işlemlerin gerçekleştirilmesi istenmektedir. Buna karşlık silme, genelleme ve yeniden kurma aşamalarıyla ilgili herhangi bir uygulama veya ilişkilendirme bulunmamaktadır. Ayrıca, özet metinlerinin değerlendirilmesiyle ilgili bir işleme yer verilmemiştir.

Dersdestek Yayınları Ortaokul ve Imam Hatip Ortaokulu Türkçe 7 Ders Kitabı

Tablo 8. Dersdestek Yayınları Ortaokul ve Imam Hatip Ortaokulu Türkçe 7 Ders Kitabı'na ilişskin Bulgular

\begin{tabular}{ccclll}
\hline Sıra & $\begin{array}{c}\text { Beceri } \\
\text { Alanı }\end{array}$ & Tema & \multicolumn{1}{c}{ Metin } & \multicolumn{1}{c}{ Etkinlik Yönergesi } & Sayfa \\
\hline 1 & Okuma & Erdemler & Kırmızı Pabuçlar & $\begin{array}{l}\text { Aşağıdaki cümleleri, hikâyedeki } \\
\text { oluş sırasına göre sıralayınız ve } \\
\text { defterinize metnin özetini yazınız. }\end{array}$ & 29 \\
\hline 2 & Okuma & Erdemler & $\begin{array}{l}\text { "Insanlığın Cesaret } \\
\text { ve Onur Simgesi: } \\
\text { Helen Keller }\end{array}$ & $\begin{array}{l}\text { "Insanlığın Cesaret ve Onur } \\
\text { Simgesi: Helen Keller" metnini } \\
\text { özetleyiniz. }\end{array}$ & 34 \\
\hline
\end{tabular}




\begin{tabular}{clllll}
\hline 3 & Okuma & Vatandaşlık & $\begin{array}{l}\text { Ak Sakallı Bilge } \\
\text { Dede }\end{array}$ & $\begin{array}{l}\text { Metnin her bölümünde biraz } \\
\text { durarak defterinize okuduğunuz } \\
\text { yerin özetini çıkarınız. } \\
\text { (“Metne Hazırlanalım” bölümünde) }\end{array}$ & 150 \\
\hline 4 & Okuma & Sağlık ve Spor & Goool! & $\begin{array}{l}\text { “Goool!” metninin nesnel bir } \\
\text { özetini defterinize yapınız. }\end{array}$ & 187 \\
\hline 5 & Okuma & Sanat & $\begin{array}{l}\text { Geleneksel El } \\
\text { Sanatları Çarşısı }\end{array}$ & $\begin{array}{l}\text { Okuduğunuz metnin özetini } \\
\text { yapınız. }\end{array}$ & 230 \\
\hline 6 & $\begin{array}{l}\text { Dinleme/ } \\
\text { İleme }\end{array}$ & $\begin{array}{l}\text { Bilim ve } \\
\text { Teknoloji }\end{array}$ & Patent & $\begin{array}{l}\text { İlediğiniz videodaki olayları } \\
\text { özetleyiniz. }\end{array}$ & 274 \\
\hline
\end{tabular}

Ders kitabında altı özetleme etkinliği bulunmaktadır. Etkinliklerin tamamında özet yazılı olarak istenmektedir. Üçüncü sıradaki etkinlik "Metne Hazırlanalım” başlığı altında yer almaktadır. Metin yapısı olan serim, düğüm ve çözüm bölümlerinin her birinde öğrencilerin durarak okudukları bölümü özetlemeleri istenmektedir.

Illk sırada yer alan özetleme etkinliğinde bir hikâyenin epizotları karışık olarak verilmiş olup öğrencilerden bunları önce sıraya koymaları, ardından metnin özetini defterlerine yazmaları istenmektedir. Öğrencilerin hikâyedeki oluş sırasını hatırlamaları bakımından olumlu bir uygulamadır.

Ders kitabı, etkinliklerin tamamında özetlemenin alt bilişsel aşamaları açısından herhangi bir yönlendirme içermemektedir. Ayrıca, özet metinlerinin değerlendirilmesine ilişkin bir uygulamaya da yer verilmemiştir.

MEB Ortaokul ve Imam Hatip Ortaokulu Türkçe 8 Ders Kitabı

Tablo 9. MEB Ortaokul ve Imam Hatip Ortaokulu Türkçe 8 Ders Kitabı'na ilişkin Bulgular

\begin{tabular}{|c|c|c|c|c|c|}
\hline Sira & $\begin{array}{l}\text { Beceri } \\
\text { Alanı }\end{array}$ & Tema & Metin & Etkinlik Yönergesi & Sayfa \\
\hline 1 & Okuma & $\begin{array}{l}\text { Millî Mücadele } \\
\text { ve Atatürk }\end{array}$ & $\begin{array}{l}\text { Vatan Yahut } \\
\text { Silistre }\end{array}$ & Okuduğunuz metni özetleyiniz. & 47 \\
\hline 2 & Dinleme & Sanat & $\begin{array}{l}\text { Bir Kış } \\
\text { Öyküsü }\end{array}$ & Dinlediğiniz metni özetleyiniz. & 119 \\
\hline 3 & Okuma & $\begin{array}{l}\text { Zaman ve } \\
\text { Mekân }\end{array}$ & Satılık Ev & $\begin{array}{l}\text { Dinlerken aldığınız notlardan } \\
\text { yararlanarak metni özetleyiniz. }\end{array}$ & 178 \\
\hline 4 & Okuma & Erdemler & $\begin{array}{l}\text { Yûnus } \\
\text { Emre'nin } \\
\text { Mezarları }\end{array}$ & $\begin{array}{l}\text { Okuduğunuz “Yûnus Emre'nin } \\
\text { Mezarları” adlı metinde } \\
\text { işaretlediğiniz bölümlerden de } \\
\text { yararlanarak metni özetleyiniz. } \\
\text { Özetinizi aşağıdaki forma göre } \\
\text { öğretmeninizle değerlendiriniz. }\end{array}$ & 192 \\
\hline 5 & Yazma & Erdemler & $\begin{array}{l}\text { Gül'ü } \\
\text { İncitme } \\
\text { Gönül }\end{array}$ & $\begin{array}{l}\text { "Yerinde söz söylemeyi bilen, özür } \\
\text { dilemek zorunda kalmaz." (Fatih } \\
\text { Sultan Mehmet) sözüyle ilgili } \\
\text { aşağıdaki adımları takip ederek bir } \\
\text { yazı yazınız. "Sonuç: Görüşlerinizi } \\
\text { birkaç cümleyle özetleyiniz." }\end{array}$ & 199 \\
\hline 6 & Okuma & $\begin{array}{l}\text { Hak ve } \\
\text { Özgürlükler }\end{array}$ & $\begin{array}{l}\text { Bilge } \\
\text { Adamın Yolu }\end{array}$ & Okuduğunuz metni özetleyiniz. & 223 \\
\hline
\end{tabular}


Türkçe Ders Kitaplarında Yer Alan Özetleme Etkinlikleri Üzerine Bir Değerlendirme

\begin{tabular}{|c|c|c|c|c|c|}
\hline 7 & Dinleme & $\begin{array}{l}\text { Hak ve } \\
\text { Özgürlükler }\end{array}$ & $\begin{array}{l}\text { Burada } \\
\text { Bülbül } \\
\text { Ağlamıs }\end{array}$ & Dinlediğiniz metni özetleyiniz. & 237 \\
\hline
\end{tabular}

Kitapta yedi özetleme etkinliği yer almaktadır. Etkinliklerin tümü yazılı özet çalışmasıdır. Üçüncü etkinlikte alınan notlardan, dördüncü etkinlikte metinde işaretlerden bölümlerden hareketle özet yapılması istenmektedir. Etkinliklerde özetleme öncesinde gerçekleştirilmesi gereken diğer işlemlere ilişkin herhangi bir yönlendirme veya ilişkilendirme yer almamaktadır. Diğer etkinliklerde doğrudan özetleme yapılması istenmektedir.

Ders kitabında beşinci özetleme uygulaması bir yazma planı içinde yer almakta, öğrencilerden metinlerinin sonuç bölümü yazarken görüşlerini birkaç cümleyle özetlemeleri istenmektedir.

Özet metinlerinin değerlendirilmesine yönelik olumlu tek uygulama bu kitapta yer almaktadır. Kitapta yer alan dördüncü etkinlikte, öğrencilerden yazdıkları özeti aşağıdaki forma (2018: 192) göre değerlendirmeleri istenmektedir:

Tablo 10. Özet Değerlendirme Formu

\begin{tabular}{|c|c|c|c|}
\hline & Evet & Kısmen & Hayır \\
\hline \multicolumn{4}{|l|}{ Kişi, yer adları vb. önemli bilgileri doğru olarak yazdım. } \\
\hline \multicolumn{4}{|l|}{ Metinde geçen olayların oluş sırasını doğru ifade ettim. } \\
\hline \multicolumn{4}{|l|}{ Metinde geçen olayları kendi cümlelerimle aktardım. } \\
\hline \multicolumn{4}{|l|}{ Olayların ayrıntıları üzerinde gereğinden fazla durmadım. } \\
\hline Özetimi metnin tümünü hatırlatacak şekilde oluşturdum. & & & \\
\hline Özete kendi görüş ve düşüncemi katmadım. & & & \\
\hline
\end{tabular}

\section{Tartışma, Sonuç}

Özetleme, dil becerilerinin kesişim noktasını oluşturan ve karmaşık bilişsel süreçler içeren önemli bir beceridir. Bilişsel olarak anlama/kavrama düzeyinde olmasına karşılık kaynağın amacına ve anlatım planına bağı kalınarak gerçekleştirilen sınırlı bir anlatımdır. Öğrenciler eğitim hayatları boyunca birçok kez özetleme görevleriyle karşı karşıya kalırlar ve tam da bu sebeple eğitim sürecinde etkili özetleme becerisi kazanmaları gerekir. Buna karşılık özetleme eğitimi verilmeden öğrencilerden özet yapmaları istenmektedir.

Özetlemenin öğrenilmesi uzunca bir süreç alır. İyi okuyucular bu konuda daha yetkin olsa da öğrencilerin çoğu bu görevi yerine getirmede çok zorlanırlar ve genellikle metnin farklı bölümlerinden kopyaladıkları cümleleri birleştirerek özet yapmaya çalışırlar. Bu durumda kaynak metindeki önemli olan birçok fikrin özette yer alması ihtimali olmayacağından öğrencilerin de metni tam olarak anlamamaları sonucunu doğurur. 
Öğrenciler açısından zorlu bir görev olarak algılanan özetlemenin uygun eğitim ortamları oluşturularak ve yeterli zaman ayrılarak öğrencilere kazandırılması hedeflenmelidir. Bu açıdan ilköğretim okullarında okuyan öğrencilere özetleme becerisinin nasıl kazandırıldığının öncelikle ortaya konması gerekmektedir.

Türkçe Dersi Öğretim Programı'nda (2018) özetleme ortaokul düzeyinde hedeflenen bir beceridir. Özetlemeyle ilgili kazanımlar 5, 6, 7, ve 8. sınıflarda yer almaktadır. Ortaokul sınıf düzeylerinde dinleme ve okuma öğrenme alanlarında "Dinlediklerini Özetler." ve "Okuduklarını özetler." şeklinde birer kazanım yer almaktadır. Bunların yanı sıra her sınıf düzeyinde okuma öğrenme alanında "Okuma stratejileri kullanır." kazanımı altında özetleyerek okuma stratejisinin kullanılması; yazma öğrenme alanında "Yazma stratejilerini kullanır." kazanımı altında özet çıkarma stratejisinin kullanılması istenmektedir. Özetlemeye ilişkin bir açıklama yapmamakla birlikte, programın farklı bölümlerde öğrenme sürecine yaptığı vurgu dikkate alındığında, özetleme gibi karmaşık bilişsel işlemler içeren bir becerinin eğitiminin süreç temelli olarak ele alınması gerektiği ortaya çıkmaktadır.

Türkçe Dersi Öğretim Programı́nda (2018) özetleme açısından yardımcı fikirlerin bulunmasıyla ilgili kazanımlar çelişki yaratmaktadır. Yardımcı fikir bulmayla ilgili 7 ve 8. sınıf düzeylerinde "Metindeki yardımc fikirleri belirler." kazanımı sadece okuma öğrenme alanında yer almaktadır. Öğrenciler yardımcı fikir bulmayı sadece okuma öğrenme alanında 7. sınıftan itibaren gerçekleştirirken özetlemeyi 5. sınıf düzeyinden itibaren gerçekleştiriyor olmaları büyük bir çelişkidir. Metinlerdeki yardımcı fikirler belirlenmeden özet yapmak söz konusu değildir.

Çalışmada 2018-2019 eğitim-öğretim yılında yürürlükte olan ortaokul Türkçe ders kitaplarındaki özetleme etkinlikleri incelenmiştir. İncelenen ortaokul ders kitaplarının tamamında 48 özetleme etkinliği yer almaktadır. Bulgular bölümünde açıklandığı gibi, etkinliklerin çoğunda, öğrencilerden doğrudan bir metnin özetini yazması istenmektedir. Bu noktada dikkat çekici olan beşinci sınıf MEB Ortaokul ve Imam Hatip Ortaokulu Türkçe Ders Kitabı'dır. Beşinci sınıflar için yürürlükte olan tek ders kitabı budur ve özetleme göreviyle öğrenciler ilk kez bu kitapta karşılaşmaktadır. Bu sınıf düzeyinde, öğrencilerin özetlemenin mantığını, işlem basamaklarını kavrayacağı varsayılmakla birlikte ders kitabında yer alan etkinliklerle bunun sağlanamayacağı söylenebilir. Kitapta bir etkinlikte örnek bir özetten hareketle metnin özetlenmesi istenirken diğer etkinliklerde doğrudan metinlerin özetlemesi beklenmektedir. Kitaptaki mevcut durum öğrencilerin ilk etkinlikteki örnek özetten hareketle özetlemenin ilkelerini kavrayacağı, sonrasında her metni özetleyebileceği varsayımını ortaya çıkarmaktadır. Oysa bu düzeyde, farklı metinlerde fikirlerin nasıl yer aldığını öğrencinin kavraması, ana fikri bulabilmesi, yardımcı fikirleri ayırt edebilmesi, ikincil bilgileri silmesi, önemli bilgileri genellemesi ve yansıtma yaparak yazarın sınırları içinde kendi özet metnini üretmesi gerekir. Söz konusu aşamaların her birinin ancak tekrarlanan etkinlikler ve öğretmen rehberliğiyle kazandırılabileceği söylenebilir. 
Türkçe Ders Kitaplarında Yer Alan Özetleme Etkinlikleri Üzerine Bir Değerlendirme

MEB Ortaokul ve Imam Hatip Ortaokulu Türkçe Ders Kitabı 7, diğer kitaplara kıyasla özetlemenin alt, bilişsel işlemlerine yer vermesi bakımından diğerlerinden farklılık göstermektedir. 11 özetleme etkinliğine yer verilen kitapta, her etkinlikte farklı olarak kullanılmakla birlikte, özetlemeyle kronolojik sıra, altı çizilen bölüm, görseller, not alma, anahtar kelimeleri not alma işlemleri ilişkilendirilmektedir. Bu diğer kitaplara göre olumlu bir özelliktir. Ancak özellikle, silme ve genelleme yapmanın öğretimine yönelik uygulamalara yer verilmemiş olduğu belirtilmelidir.

Sözlü özetleme uygulamalarına ders kitaplarında çok az yer verildiği tespit edilmiştir. Ders kitaplarının tamamında yer alan 48 özetleme etkinliğinden sadece dördü sözlü özetleme etkinliğidir. Bu etkinliklerden ikisi Eksen Yayıncılık 6. sınıf ders kitabında, biri MEB Yayınları Türkçe 7 Ders Kitabı ve biri de MEB Yayınları Türkçe Ders Kitabı 7'de yer almaktadır. Bu sonuç sözlü özet uygulamalarının sayısının artırıması gerektiğini ortaya koymaktadır.

Tüm ders kitapları içinde özet metinlerinin değerlendirilmesine yönelik tek uygulama 8. sınıf MEB Ortaokul ve Imam Hatip Ortaokulu Türkçe Ders Kitabı'ında yer almaktadır. Öz değerlendirme olarak düzenlenen bu form veya benzer başka bir değerlendirme aracı, kitapta yer alan diğer 6 etkinlikte bulunmamaktadır. Öz değerlendirme, akran değerlendirme, kontrol listesi şeklinde oluşturulan değerlendirme formları öğrencilerin özetlemede nelere dikkat edeceklerini görmelerine ve yeni görevlerinde bunu yerine getirmelerine aracılık edeceğinden son derece önemlidir.

Ortaokul düzeyinde bir öğrenme-öğretme hedefi olarak belirlenen ve kazanıma dönüştürülen özetleme becerisinin ders kitaplarında yer alan etkinliklere göre değerlendirildiği bu çalışmada ortaya çıkan sonuç, öğrencilerin büyük ölçüde özetlemeyi biliyor veya sadece özetleyiniz göreviyle kendilerinin başarabilecekleri varsayımına sahip olunduğudur. Öğrencilerden silme, genelleme ve yeniden kurma işlemlerini rehberlik etmeden, deneyim yaşatmadan başarmalarını beklemek önemli bir sorundur.

\section{Öneriler}

Çalışmadan elde edilen sonuçlara göre şu önerileri yapmak mümkündür:

1. Özetlemenin bilişsel yükleri dikkate alınarak etkinliklerin oluşturulması ve bu bilişsel işlemlerin birbiriyle ilişkilendirilmesi gerekir.

2. Özetleme becerisinin kazanılması bilişsel süreçlere uygun etkinlikler aracılığı ve etkili öğretmen rehberliğiyle mümkün olabilir.

3. Öğretmenler özetleme eğitimi konusunda desteklenmelidir.

4. Özetleme için en az bir eğitim-öğretim yılının ayrılması gerekmektedir.

5. Öğretmenlerin özetleme eğitimi konusundaki yeterliliklerine yönelik çalışmalar yapılmalıdır. 


\section{Kaynaklar}

Ağın Haykır, H., Kaplan, H., Kıyar, A., Tarakçı, R. \& Üstün, E. (2018). Ortaokul ve imam hatip ortaokulu Türkçe ders kitabı 5. Ankara: MEB Yayınları.

Akgül, A., Demirer, N., Gürcan, E., Karadaş, D., Karahan, I. \& Uysal, A. (2018). Ortaokul ve imam hatip ortaokulu Türkçe 7. sınıf ders kitabı 7. Ankara: MEB Yayınları.

Ceylan, S., Duru, K. Erkek, G. \& Pastutmaz, M. (2018). Ortaokul ve imam hatip ortaokulu Türkçe 6 ders kitabı. Ankara: MEB Yayınları.

Cho, Y. (2012). Teaching summary writing through direct instruction to improve text comprehension for students in ESL/EFL classroom. MA Thesis, University of Wisconsin-River Falls.

Creswell, John W. (2016). Nitel araştırma yöntemleri: beş yaklaşıma göre nitel araştırma ve araştırma deseni. çev. Mesut Bütün, Selçuk Beşir Demir. Ankara: Siyasal Kitabevi.

Deneme, S. \& Demirel, Ö. (2012). Yabancı dilde yazma becerisinin gelişiminde özetleme tekniğinin öğretimi ve başarıya etkisi. Dil Dergisi, (157), 49-64.

Dilidüzgün, Ş. (2008). Türkçe öğretiminde metindilbilimsel bağlamda uygulamalı bir yaklaşım. istanbul: Yayımlanmamış Doktora Tezi, İstanbul Üniversitesi Sosyal Bilimler Enstitüsü.

Dilidüzgün, Ş. (2013). Ortaokul Türkçe derslerinde okumadan özet yazmaya. Ankara Üniversitesi Eğitim Bilimleri Fakültesi Dergisi, 46(2), 47-68.

Karatay, H. (2014). Okuma eğitimi-kuram ve uygulama. Ankara: Pegem Akademi.

Kaya, B. (2018). Ortaokul ve imam hatip ortaokulu Türkçe ders kitabı 7. Ankara: Dersdestek Yayınları.

Kır, T., Kırman, E. \& Yağız, S. (2018). Ortaokul ve imam hatip ortaokulu Türkçe ders kitabı 7 (2). Ankara: MEB Yayınları.

Kim S.-A. (2001). Characteristics of EFL readers' summary writing: A study with Korean university students. Foreign Language Annals, 34 (6), 569- 581.

Kintsch, W., Van Dijk, T. A. (1978). Towards a model of text comprehension and production. Psychological Review, $85,363-394$.

Marzec-Stawiarska, M. (2016). Foreign language writing anxienty among adult advanced learners of english. Linguistica Silesiana (33), 221-239.

Mete, G., Karaaslan, M., Kaya, Y., Ozan, Ş. \& Özdemir, D. (2028). Ortaokul ve imam hatip ortaokulu Türkçe 8 ders kitabı. Ankara: MEB Yayınları.

MEB. (2018). Türkçe dersi öğretim programı (ilkokul ve ortaokul 1,2,3,4,5,6,7 ve 8. sınıflar). Ankara: Talim ve Terbiye kurulu Başkanlığı.

Senemoğlu, N. (2018). Gelişim öğrenme ve öğretim-kuramdan uygulamaya. Ankara: Anı Yayıncılık.

Sönmez, V., \& Alacapınar G. F. (2014). Örneklendirilmiş bilimsel araştırma yöntemleri. Ankara: Anı Yayıncılık.

Şekerci, Y. (2018). 6. sınıf ortaokul türkçe ders kitabı. İstanbul: Eksen Yayıncılık.

TDK. (2011). Türkçe sözlük. Ankara: Türk Dil Kurumu Yayınları.

Ülper, H. ve Karagül, S. (2011). Özetleme becerisinin kazandırılmasına yönelik etkinlikler: Ders kitapları temelinde bir araştırma. (Ed.: V. D. Günay, Ö. Fidan, B. Çetin ve F. Yıldız), Türkçe Öğretimi Üzerine Çalışmalar. İzmir: Dokuz Eylül Üniversitesi Yayınları, s. 145-155. 


\section{Extended Abstract}

Summarizing means presenting a written thought, a monitored content, a text that is heard or read, in written or oral form, which is shorter and reflect its essence. The ability to summarize involves complex cognitive processes. Due to complex cognitive processes, the summarization process includes multiple stages. To summarize, a student should be able to comprehend important ways of emphasizing important points, distinguish significant information from insignificant one, take notes, determine the subject of the text, find the main idea and supporting ideas, and analyze the text type and structure. In the process of summarizing a narrative text or an informative text, students are expected to use classification, sorting, evaluation and decision-making skills.

Kintsch and van Dijk (1978) describe the steps of elimination, generalization and reconstruction by emphasizing that the propositions in the small-scale and large-scale text structure should be selectively processed as a text comprehension model. Multiple cognitive processes take place under elimination, generalization, and reconstruction phases, and basic skills are used for these processes. For elimination, it is necessary to determine the information in the text first, and to classify it, then to compare it and finally to decide which ones are important and which are not. In the generalization, the upper categories, that is, the general concept which conveys the meaning are found out by categorizing the concepts in the text. In addition, it is necessary to generalize the propositions by considering sub-action characteristics between actions. At the stage of reconstruction, generalizations are evaluated, and the abstract text is constructed within the boundaries of the author.

Students encounter the summarizing frequently in their formal education. Summarizing is an indication of the level of understanding of the text by the students as well as the level of general narrative. For this reason, curriculum should aim that the students gain an ability to summarize effectively.

In this study, it has been investigated how the Turkish Language Teaching Program (2018) aims to provide students in the areas of listening, reading and writing at the middle school in Turkish textbooks. For this purpose, in 2018-2019 academic year, 7 summarizing activities- one for the $5^{\text {th }}$ grades, two for the $6^{\text {th }}$, three for the $7^{\text {th }}$ and one for the $8^{\text {th }}$ grades- in the Turkish coursebooks accepted by the Ministry of National Education (MONE) were examined.

\section{Method}

This is a case study. It is a holistic single case study that provides in-depth information gathering, description, and thematic representation (Creswell, 2016) about a situation through informative documents. The samples of the study are Turkish Language Teaching Program published in 2018, 7 secondary schools in the 20182019 academic year and Turkish textbooks in secondary schools of imam hatip.

\section{Result and Discussion}

In the study, Turkish Course Curriculum (2018) initiates summarizing as "he/she summarizes" and only "he/she summarizes the texts" in listening and reading learning areas in the $5^{\text {th }}-$ the $8^{\text {th }}$ grades. In addition, reading by summarizing and summary writing are presented as a method required to be used in the $7^{\text {th }}$ and $8^{\text {th }}$ grades for reading and writing learning areas.

Four of these activities are oral summary, 44 are written summary. There was no summarization activity in the textbooks in which the cognitive processes of summarizing were discussed and graded. In most of the activities, it was found that the summary task did not include any explanation or association related to the cognitive steps. In 14 out of 48 summarizing events, there were instructions such as "summarize the text according to the statements you underlined while reading" and "summarize the text by using the notes you have taken in your notebooks" and also "summarize the text you have read in a chronological and logical order". This is not a guideline for students about elimination and generalization processes that are critical for summarizing.

The main finding of the study shows that most summarization activities in Turkish textbooks are not formed in accordance with the cognitive processes of summary and a direct summary of the text is requested from the students. In addition, large majority of the summary results are in written form, and applications for the evaluation of summary texts are presented only once.

Acquiring summary skills may be possible through appropriate activities for cognitive processes and effective teacher guidance. Considering the cognitive load of summary, creating the activities and associating these cognitive processes with each other is very important for the students to be able to summarize. For this reason, at least one school year should be reserved for the summarization. 